\title{
Expanding State Initiation and Enforcement Under Superfund
}

\author{
James P. Young †
}

A young congressman named David Stockman rose to the floor of the House of Representatives on September 23, 1980, to oppose the creation of a "Superfund" that the Environmental Protection Agency (EPA) would use to clean up the nation's hazardous waste dumps. He challenged the proponents of Superfund to present information showing why "this one problem, of all the problems we face in this country today, could not be handled by the states if we give them some encouragement. [The Congress and the EPA] cannot do everything." Representative John LaFalce answered Stockman's challenge, claiming that "[s]tates cannot handle" hazardous waste cleanup because "it is a problem that is nationwide in scope and is deserving of a comprehensive legal framework."'

Although hazardous waste is a "nationwide" problem in the sense that every state contains hazardous waste sites, it is not nationwide in the sense usually associated with environmental harms; that is, hazardous waste is not a problem that routinely transcends the boundaries of a single state. Representative LaFalce's comments hid the real source of congressional discontent: the states had failed to respond to the problem. ${ }^{3}$ Whatever Congress's motivation, Stockman was defeated, and Congress subsequently created the Superfund under the Comprehensive Environmental Response, Compensation, and Liability Act of 1980 (CERCLA). ${ }^{4}$

Although the EPA has cleaned thousands of hazardous waste sites-largely by itself-in the decade since Congress passed

$\dagger$ B.A. 1987, University of Florida; J.D. Candidate 1991, The University of Chicago.

126 Cong Rec 26765 (September 23, 1980). Stockman noted that the committee report's treatment of "[e]vidence of inadequate local and State response" contained only three cases: "one which occurred 7 years ago; another of them which could not occur now under [the Resource Conservation and Recovery Act of 1976] and the third one was Love Canal."

Id.

- For an example of this view, see id at 26760-61 (remarks of Rep. Florio) ("Many states, quite frankly, are not interested or are not capable of going forward. And they do not want to.").

4 Pub L No 96-510, 94 Stat 2767 (1980), codified at 42 USC §§ 9601-9675 (1982 \& Supp 1989). 
CERCLA, this represents only a small fraction of the sites that will eventually need attention under the statutory program. ${ }^{\circ}$ As of this writing, the EPA has placed over 1,175 sites on its "National Priorities List," yet the agency has begun cleanup operations at only 254 of those sites, ${ }^{7}$ and government officials estimate that the EPA may eventually be called upon to clean up at least 10,000 sites. $^{8}$ Congress authorized $\$ 8.5$ billion for hazardous waste cleanup between 1986 and 1991, but the cost may ultimately exceed $\$ 100$ billion. ${ }^{9}$

From the beginning, Congress envisioned a secondary, supporting role for the states in performing cleanups. In CERCLA, Congress concentrated power in the federal government, even though most of the economic rationales underlying centralization in environmental regulation-for example, externalities among states or economies of scale from concerted interstate action ${ }^{10}$-are not present in hazardous waste cleanup. Most Superfund sites are located within a single state that could handle the cleanup on its own, and some evidence suggests that state governments are interested in taking more control of cleanup actions within their borders. States are better positioned to respond to local concerns than the EPA, which is only indirectly politically accountable to local communities.

This Comment proposes that Congress adopt two structural changes to CERCLA. First, states should control initiation and implemention of hazardous waste cleanups. This recommendation comports with principles of federalism and enhances political accountability. Second, states should have the right to seek federal injunctions against polluters, just as the federal government now can under CERCLA. ${ }^{11}$ The government's right to obtain injunctive relief complements its power to initiate cleanups. Most importantly, the government can achieve cleanups more cheaply and

\footnotetext{
- See Office of Technology Assessment (OTA), Doc No OTA-ITE-232, Superfund Strategy 3 (1985).

See note 20 and accompanying text.

7 BNA Envir Daily 4 (October 31, 1989).

${ }^{8}$ OTA, Superfund Strategy at 3 (cited in note 5).

Id.

${ }^{10}$ See Richard B. Stewart, Pyramids of Sacrifice? Problems of Federalism in Mandating State Implementation of National Environmental Policy, 86 Yale L J 1196, 1212, 121516 (1977).

${ }^{11} 42$ USC \$ 9606(a). In practice, this provision has allowed the federal government to obtain injunctive relief. See, for example, B. F. Goodrich v Murtha, 697 F Supp 89 (D Conn 1988).
} 
quickly through injunctions than if it had to undertake them itself and later sue for reimbursement.

Section I of this Comment sets forth the general structure of CERCLA and describes the balance of power between the federal government and the states under the current CERCLA scheme. Section II provides an introduction to the array of state "miniSuperfund" statutes and their uneasy coexistence with CERCLA. Section III analyzes some of the policy problems that arise from the current system, especially in light of federalism principles. Section IV presents a proposal to improve the process of hazardous waste cleanup.

\section{The Current Role of the States Under Cercla}

\section{A. The General Structure of CERCLA}

In 1979, the evacuation at Love Canal in New York drew national attention to the problem of hazardous waste sites and increased pressure on Congress to pass legislation concerning cleanup procedures. ${ }^{12}$ The Resource Conservation and Recovery Act of 1976 (RCRA) $)^{13}$ already provided "cradle to grave" regulation of hazardous wastes, but RCRA's considerable federal enforcement power did not extend to waste dumps created before the enactment of the statute. ${ }^{14}$ In the final days of the 1980 congressional term, Congress passed CERCLA. The statute imposed taxes on the chemical industry to fund the Hazardous Substance Superfund (the "Superfund"), which would finance EPA cleanups of hazardous waste sites. ${ }^{15}$ CERCLA also established, in general terms, the procedures and standards to be followed in carrying out the cleanups.

The original version of CERCLA was the product of a hastily worked-out compromise. It was passed with almost no debate and

12 Frank P. Grad, A Legislative History of the Comprehensive Environmental Response, Compensation and Liability ("Superfund") Act of 1980, 8 Colum J Envir L 1, 7-8 (1982). See generally Samuel S. Epstein, Lester O. Brown, and Carl Pope, Hazardous Waste in America (Sierra Club, 1982).

13 Pub L No 94-580, 90 Stat 2795 (1976), codified as an amendment to the Solid Waste Disposal Act, 42 USC $§$ 6901-6992k (1982 \& Supp 1989).

1442 USC § 6973. See also Donald W. Stever, I Law of Chemical Regulation and Hazardous Waste $\$ \S 6.03-6.05$ (Clark Boardman, 1989); and Pennsylvania v Union Gas Co., 109 S Ct 2273, 2285 (1989).

1s See Grad, 8 Colum J Envir L at 1 (cited in note 12). 
under a suspension of the rules. ${ }^{16}$ As a result of this unorthodox process, the drafters of CERCLA gave insufficient thought to such basic features of the statute as the liability rules and the mechanics of implementation. ${ }^{17}$ Therefore, Congress tried to correct these problems when it reauthorized money for the Superfund under the Superfund Amendments and Reauthorization Act of 1986 (SARA). ${ }^{18}$ Substantive changes in CERCLA included setting deadlines for the EPA on cleanups, specifying settlement policy, and ensuring defendants' right to contribution. Congress also increased the 1986-1991 Superfund authorization to $\$ 8.5$ billion.

As amended, CERCLA contains several major provisions governing the orderly cleanup of hazardous waste sites. It requires the President to revise the National Contingency Plan to "establish procedures and standards for responding to releases of hazardous substances." 19 CERCLA also authorizes the EPA to investigate sites, and requires the agency to compile a National Priorities List $^{20}$ of sites that present the greatest danger ${ }^{21}$ The EPA can use the Superfund to finance "remedial actions,"22 defined as "those actions consistent with permanent remedy [sic] taken instead of or in addition to removal actions in the event of a release or threatened release of a hazardous substance into the environment." ${ }^{23}$ Remedial actions include site-specific actions such as "storage, confinement, ... neutralization, cleanup ..., recycling or reuse, repair or replacement of containers, . . . incineration"; they also include relocation of residents and offsite transport and storage. ${ }^{24}$ The EPA may then sue polluters for reimbursement of the

\footnotetext{
${ }^{16}$ Grad, 8 Colum $J$ Envir $L$ at 1 (cited in note 12).

${ }^{17}$ See In re Acushnet River \& New Bedford Harbor Proceedings re Alleged PCB Pollution, 675 F Supp 22, 25-26 n 2 (D Mass 1987).

1s Pub L No 99-499, 100 Stat 1613 (1986), codified as an amendment to CERCLA, 42 USC $\$ \S 9601-9675$.

${ }_{19} 42$ USC $\S 9605(a)$. The President, in turn, has delegated this task, along with most of his authority under CERCLA, to the EPA. See id. The National Contingency Plan already existed as part of the Federal Water Pollution Control Act (now called the Clean Water Act), 33 USC §§ 1251-1387 (1982 \& Supp 1989). The Plan's official name is the National Oil and Hazardous Substances Pollution Contingency Plan, and is described at 40 CFR $\S 300$ (1989). Before CERCLA, the National Contingency Plan served as a blueprint for dealing with environmental disasters such as oil spills. See Joseph Freedman, Proposed Amendments to the National Contingency Plan: Explanation and Analysis, 19 Envir L Repr 10105, 10105-07 (1989).

20 The National Priorities List is found at 40 CFR $\S 300$, Appendix B (1989).

2142 USC \$ 9605 .

${ }^{22}$ Remedial actions are confined to sites that appear on the National Priorities List. 40 CFR § 300.68(a)(1) (1986).

${ }^{23} 42$ USC § $9601(24)$ (emphasis added).

24 Id.
} 
costs of the remedial action. ${ }^{28}$ Liability under CERCLA is strict, joint, and several. ${ }^{26}$

Other key provisions of CERCLA deal with emergency situations. When the EPA concludes that a hazardous waste site requires a quick response, it can undertake a "removal,"27 which is defined simply as "the cleanup or removal of released hazardous substances from the environment."28 In addition, when the President believes that a certain site presents an "imminent and substantial endangerment to the public health or welfare or the environment," he can require the Attorney General to file an action for federal injunctive relief to abate the danger. ${ }^{29}$ SARA also clarifies the government's power to reach settlements with offenders, requiring that all settlements involving remedial actions be entered as consent decrees. ${ }^{30}$

\section{B. The State's Role in CERCLA}

This subsection explores the several provisions of CERCLA that delineate permissible state involvement in federal Superfund operations. ${ }^{31}$ The paradigmatic case under CERCLA involves an action initiated by the EPA, with limited state involvement confined to certain points in the cleanup process. In addition, however, states may recover some of their own response costs under CERCLA, to the extent that the state action is consistent with the National Contingency $\mathrm{Plan},{ }^{32}$ or if the state is protecting its natural resources. ${ }^{33}$

${ }^{25} 42$ USC \& 9607(a)(4)(A).

${ }^{20}$ See 42 USC § 9607 . While the statute does not specify the standard of liability, courts have concluded that liability is strict, joint, and several. See, for example, United States v Monsanto, 858 F2d 160, 166-68 (4th Cir 1988); and United States v Conservation Chemical Co., 628 F Supp 391, 417-20 (W D Mo 1985), as supplemented Jan 9, 1986.

${ }^{27} 42$ USC \& 9604(a).

2842 USC \& 9601(23). A removal differs from a remedial action in that the EPA may not spend more than two million dollars or twelve months on a removal. 42 USC $\S 9604(c)(1)$.

2942 USC \& 9606(a).

so 42 USC \& 9622(d)(1)(A). This provision of SARA was added to remedy the perception that the EPA had entered a number of "sweetheart deals" with potentially responsible parties. For an example of such a deal, see United States $v$ Seymour Recycling Corp., $554 \mathrm{~F}$ Supp 1334 (S D Ind 1982). Congress intended the consent decree requirement to provide independent judicial oversight. See Comment, Consent Decrees Under the Superfund Amendments and Reauthorization Act of 1986: Controlling Discretion With Procedure, 1987 U Chi Legal F 451, 452-55.

s1 See 42 USC $\$ \$ 9604,9605(\mathrm{a})(8)(\mathrm{B}), 9621(\mathrm{f})$.

342 USC \& 9607(a).

3s 42 USC § 9607(f). 
1. When the federal government responds first.

In the typical remedial action contemplated by CERCLA, the EPA identifies, investigates, analyzes, and cleans up the hazardous waste site. The states have a significant, if secondary, role in this process: states must submit suggestions for sites to be included on the National Priorities List," ${ }^{34}$ and must be permitted "substantial and meaningful involvement" in the "initiation, development, and selection of remedial actions" within the state. ${ }^{35}$ In addition, the EPA cannot spend Superfund money without securing an agreement from the affected state to pay at least ten percent of the cost of the remedial action; ${ }^{36}$ the affected state must also agree to maintain the site in the future and to provide a federally-approved disposal facility for the wastes removed. ${ }^{37}$

CERCLA's displacement of the states in the cleanup process creates potential sources of friction between the federal and state governments. For example, if the EPA decides to undertake a remedial action, the state may apply to the EPA to participate in or to perform the action itself, but the decision lies wholly with the EPA. ${ }^{38}$ Although the EPA may want states to assume a larger role in the cleanups, it seems to doubt that they will do an acceptable job. ${ }^{39}$ Another potential source of friction is the EPA's power to propose remedies during settlement talks even when the remedies do not meet state standards; federal courts are not bound to honor a state's request that its standards be followed..$^{40}$ Once the EPA decides to clean up a site, these structural and institutional biases often result in the states being sidelined during the cleanup process.

2. When the state responds first under CERCLA.

Because CERCLA delegates substantial authority to a federal agency, it is usually the federal government and not the states that initiates cleanup measures. Nevertheless, there are two opportunities under CERCLA itself for a state to recover the costs of a cleanup. First, the general liability section, 42 USC $\S 9607$, allows

3442 USC $\S 9605(\mathrm{a})(8)(\mathrm{B})$.

ss 42 USC $\$ 9621(f)(1)$.

s6 42 USC $\$ 9604(\mathrm{c})(3)(\mathrm{C})$.

s7 42 USC $\$ 9604(\mathrm{c})(3)(\mathrm{B})$.

38 42 USC $\$ 9604$ (a). See also Freedman, 19 Envir L Repr at 10135 (cited in note 19).

so See Freedman, 19 Envir L Repr at 10116 (cited in note 19).

40 42 USC $\S 9621$ (f). For examples of state standards, see Section II; for examples of how this friction plays out, see Section III. 
"persons," which includes states, ${ }^{41}$ to recover response costs from cleanups that are consistent with the National Contingency Plan. ${ }^{42}$ Second, each state is made the trustee of the natural resources in that state (unless they are controlled by the federal government) and is entitled to sue polluters who destroy those natural resources. ${ }^{43}$ States may act under federal law pursuant only to these provisions. CERCLA does not, however, prevent states from using their own laws to cleanup sites on the National Priorities List. ${ }^{44}$

The right to sue polluters directly for injunctive relief under CERCLA, as the federal government can under $\S 9606$, would give the states a powerful enforcement tool. The economizing feature of injunctions would mitigate the cost of cleaning the large number of sites that need attention within a reasonable time frame. ${ }^{45}$ Since the only costs the government must bear up front when bringing a suit for an injunction are the costs of maintaining the action, a state could initiate more cleanups at one time. Therefore, expanding the power of the states to obtain injunctions in federal court should result in more sites being cleaned up more quickly.

The question whether states in fact possess such a right has been hotly debated. As part of SARA, Congress added the following provision to CERCLA: "A State may enforce any Federal or State standard, requirement, criteria, or limitation to which the remedial action is required to conform under this Act in the United States district court for the district in which the facility is located."46 Although this provision appears at first blush to authorize states to initiate actions for injunctive relief, an examination of

4142 USC § 9601(21).

42 The EPA has set out guidelines for state compliance with the National Contingency Plan in cleanups not involving the federal government. For example, when undertaking a remedial action, the state must satisfy the Plan's provisions relating to remedial investigations, cost-effective responses, and opportunity for public comment. Prior approval of the EPA, however, is not required. See generally 40 CFR § 300.71 (1989); see also State of New York v Shore Realty Corp., 759 F2d 1032, 1045-47 (2d Cir 1985).

is The state can recover damages, which must be used to "restore, replace, or acquire the equivalent of such natural resources." 42 USC $\S 9607(f)(1)$. See also Idaho v Hanna Mining Company, 882 F2d 392 (9th Cir 1989).

46 See 42 USC \$ 9614(a); Superfund Amendments and Reauthorization Act of 1986, HR Rep No 962, 99th Cong, 2d Sess 248 (1986), reprinted in 5 USCCAN 3276, 3341.

is For the projected costs of the Superfund program, see OTA, Superfund Strategy at 7 (cited in note 5).

4s 42 USC § 9621(e)(2). The statute goes on to provide, "Any consent decree shall require the parties to attempt expeditiously to resolve disagreements concerning the implementation of the remedial action informally with the appropriate Federal and State agencies. Where the parties agree, the consent decree may provide for administrative enforcement." 
CERCLA's structure and legislative history suggests that, in fact, it does not so empower the states.

The two courts that have addressed this issue have reached opposite conclusions. In Colorado $v$ Idarado Mining $\mathrm{Co}_{0},{ }^{47}$ the district court in Colorado held, without analysis, that CERCLA's state enforcement provision ( $\$ 9621(\mathrm{e})(2)$ ) allows states to sue for injunctions against polluters in federal court, even if the federal government has taken no action with respect to that site. Conversely, in United States $v$ Akzo Coatings of America, Inc., ${ }^{48}$ a district court in Michigan held that $\S 9621(\mathrm{e})(2)$ allows states to sue for injunctions only to enforce the provisions of existing consent decrees.

Three reasons suggest that the Idarado court incorrectly interpreted $\S 9621(e)(2)$. First, the court resorted to a plain meaning argument, simply quoting the sentence about safe enforcement and stating, "Thus injunctive relief is also available to the state under CERCLA."49 But this argument ignores the larger statutory context of $\S 9621(\mathrm{e})(2)$. The state enforcement provision applies only to "remedial action[s] selected under section [9604] or secured under section [9606]." "'50 Those sections of CERCLA authorize only the federal government to initiate Superfund projects, not the states. $^{51}$

Second, the immediate context of the provision strongly suggests that the grant of enforcement power to the states is confined to existing consent decrees. The phrase immediately following the grant of enforcement power in $\S 9621(\mathrm{e})(2)$ - "Any consent decree shall require"-suggests that the previous sentence refers only to situations in which a consent decree exists. It is unlikely that Congress intended an isolated sentence to create a broad new stateinitiated remedial action, especially since the President himself may sue for injunctions only when the hazardous waste poses an "imminent and substantial endangerment to public health."

Third, the legislative history of the provision argues convincingly against broad remedial powers for the states. The House Report explains the purpose of $\S 9621(\mathrm{e})(2)$ as follows: "States are given the authority to enforce requirements of consent decrees to

47707 F Supp 1227, 1232 (D Colo 1989).

4719 F Supp 571, 577-80 (E D Mich 1989).

${ }^{40}$ Idarado, 707 F Supp at 1232.

so 42 USC § 9621 (d)(2).

${ }^{32}$ See, for example, Cadillac Fairview/California v Dow Chemical Co., 840 F2d 691, 697 (9th Cir 1988).

${ }^{82} 42$ USC § 9606(a). 
which the remedial action must conform."'ss Although the actual language of $\S 9621(\mathrm{e})(2)$ is not clear on its face, the best reading of the statute appears to limit state enforcement power to existing consent decrees.

\section{State Responses Under State Law}

As noted earlier, the drafters of CERCLA hoped to fill the void created by the states' inability or unwillingness to address hazardous waste cleanup. ${ }^{54}$ At the same time they sought to centralize federal control over cleanup actions, however, the drafters wanted the states to assume a large portion of the burdens CERCLA would impose, both in terms of money and resources. A potential conflict thus arose: as states passed legislation and developed infrastructures to meet their financial responsibilities under CERCLA, they inevitably sought greater control over hazardous waste cleanup.

CERCLA originally required states to contribute money to each remedial action, ${ }^{55}$ but simultaneously withheld control from the states by forbidding them from using state tax dollars to pay "compensation for claims for any costs of response or damage or claims which may be compensated under this title." preme Court ruled in Exxon Corp. $v$ Hunt $^{37}$ that this CERCLA provision ( $\S 9614(c)$ ) preempted any state fund designed to pay for the "same types of expenses that may be paid by Superfund."ss Under this interpretation, a state was prohibited from undertaking a remedial action on its own if the cleanup were eventually to be handled by the EPA under CERCLA, even if the federal government had not yet spent money at the site.

Congress responded to Hunt with SARA, removing the state compensation proscription from CERCLA. ${ }^{59}$ The accompanying conference report explained that the deletion "clarifie[d] that States are not preempted from imposing taxes for purposes already covered by CERCLA." ${ }^{60}$ Elsewhere the conference report states that the new provision does not "restrict the right of a state to undertake a clean-up or to recover the costs of the clean-up under

\footnotetext{
3s HR Rep No 962 at 249 (cited in note 44).

* See note 3.

ss 42 USC \$ 9604(c)(3)(C).

se 42 USC $\$$ 9614(c) (removed in 1986 by SARA).

${ }^{87} 475$ US 355 (1986).

ss Id at 370 .

6. Pub L No $99-499,100$ Stat 1613,1652 (1986).

so HR Rep No 962 at 225 (cited in note 44).
} 
State law or CERCLA." ${ }^{11}$ Congress, therefore, recognized that state Superfund projects could play an important adjunct role in the cleanup of hazardous wastes.

Because SARA answered the fundamental questions about the permissible scope of state Superfund laws, almost all states have adopted such laws. ${ }^{62}$ The statutes adopt many different approaches to hazardous waste cleanup. Similar to CERCLA, some state laws

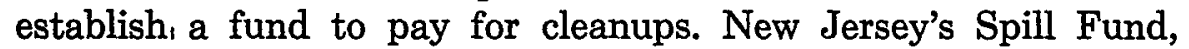
which pre-dates CERCLA, is a good example of this approach. ${ }^{63}$ Other states have cleanup programs that are more modest in scope. Colorado's hazardous substances statute, for example, provides that state authorities must respond to emergency spills and gives a right of reimbursement to the Attorney General and private par-

61 Id at 248 .

${ }^{62}$ Ala Code $\S \S 22-30 A-1$ to 22-30A-11 (1975 \& Supp 1989); Alaska Stat $\S 46.08 .005$ et seq (1987 \& Supp 1989); Ariz Rev Stat Ann §§ 36-1851 et seq (West 1956 \& Supp 1989); Ark Stat Ann §§ 8-7-501 et seq (1987 \& Supp 1989); Cal Health and Safety Code \$§ 25300 et seq (West 1984 \& Supp 1989); 1989 Colo Rev Stat \$\$ 25-16-101 et seq, §§ 29-22-101 et seq; Conn Gen Stat Ann $\S \S 22 a-114$ et seq, $\S \S 22 a-748$ et seq (West 1985 \& Supp 1989); Fla Stat $\S \S 403.141,403.161,403.703,403.725$, and 403.726 (1988); Off Code Ga Ann \$§ 12-8-60 et seq (Michie 1988 \& Supp 1989); Ill Ann Stat ch 1111/2, §§ 1003, 1022.2 (Smith-Hurd 1988 \& Supp 1989); Ind Code Ann $\S \S 6-6-6.6-1$ et seq, $\S$ 13-7-8.6-1 et seq (West 1983 \& Supp 1989); Iowa Code Ann $\$ \S 455 B .423$ et seq (West Supp 1989); Kan Stat Ann $\$ \S 65-3430$ et seq (1985 \& Supp 1988); Ky Rev Ann Stat §§ 224.868 et seq (1982 \& Supp 1988); La Rev

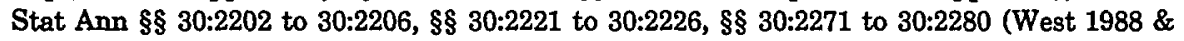
Supp 1990); 38 Me Rev Stat Ann §§ 1319-B to 1319-K (1989 \& Supp 1990); Md Health and Environmental Code Ann $\S$ 7-201, 7-218 to 7-221, 7-266 (1982 \& Supp 1986); Mass Ann Laws ch 21E, §§ 1-13 (Michie/Law Co-op 1988); Mich Comp Laws Ann §§ 299.501 et seq (West 1984 \& Supp 1989); Minn Stat Ann §§ 115B.01 et seq (West 1987 \& Supp 1990); Miss Code Ann §§ 17-17-3 and 17-17-5 (Law Co-op Supp 1989); Mo Ann Stat § 260.350, §§ 260.435 et seq, $\$ \S 260.500$ et seq (Vernon Supp 1989); Mont Code Ann $\$ \S 75-10-701$ et seq (1987); Nev Rev Stat $\S \S 459.400$ et seq, $\S 353.263$ (1987 \& Supp 1989); NH Rev Stat Ann $\S \S$ 147-B:1-11 (Equity Supp 1989); NJ Stat Ann §§ 58:10-23.11 et seq (West 1982 \& Supp 1989); NM Stat Ann $\S$ 74-4-3, 74-4-7, and 74-4-8 (1989); NY State Finance Law § 97-2, NY Envir Conservation Law \$§ 27-0900 et seq, 71-2723, 71-2725, 27-1301 to 27-1319, NY Public Health Law $\S \S 1389-$ a to $1389-d$ (McKinney 1984 \& Supp 1990); NC Gen Stat $\$$ 130A-290 (1986 \& Supp 1989), 143-215 (1987); ND Cent Code \$\$ 23-31-01 to 23-31-03 (Supp 1989); Ohio Rev Code Ann § 3734 (Page 1988 \& Supp 1989); 63 Okla Stat Ann §§ 1-2015 to 1-2021 (West $1984 \&$ Supp 1990); Or Rev Stat $\$ \$ 466.005,466.150,466.155,466.160,466.200$, and 466.205 (1989); 35 Pa Cons Stat Ann § 6018 (Purdon Supp 1989); RI Gen Laws §§ 23-19.1-4 and 23-19.1-22 (1987 \& Supp 1989); SC Code Ann $\$ \S 44-56-20,44-56-160,44-56-170,44-56-$ 180, 44-56-190, and 44-56-200 (Law Co-op 1985 \& Supp 1989); Tenn Code Ann \$§ 68-46-201 et seq (1983 \& Supp 1989); Tex Water Code Ann \$§ 26.261 et seq, §§ 26.301 to 26.307 (Vernon 1988 \& Supp 1990); 10 Vt Stat Ann §§ 1251, 1263(a), 1265(a), 1265(d)(5), 1265(e), 1282, and 1283 (Equity $1984 \&$ Supp 1989); Va Code $\$ \S 32.1-177,32.1-178$, and 32.1-182 (1985 \& Supp 1989); Wash Rev Code Ann $\$ \$ 70.105$ et seq (West Supp 1989); W Va Code $\S$ 20-5G-1 to 20-5G-6 (1989); Wis Stat Ann $\$ \S 144.43,144.441,144.61,144.62$, and 144.76 (West 1989).

es NJ Stat Ann §§ 58:10-23.11 et seq. 
ties, ${ }^{64}$ but does not set aside a large fund for cleaning up the kind of long-standing dump sites covered by CERCLA. Almost all states empower selected officials to initiate cleanup actions of one kind or another, but most of these statutes are designed to take up where CERCLA leaves off.

The history of CERCLA has been marked by a slowly increasing willingness on the part of the federal government to expand state involvement in the CERCLA program, ${ }^{65}$ but always keeping the states in a secondary role. While the newly revised National Contingency Plan (which took effect April 9, 1990) is meant to establish a "partnership" between the federal and state governments, the federal government has kept ultimate control of the program for itself. For example, the EPA declined to delegate to the states the power to select remedies for hazardous waste sites. ${ }^{66} \mathrm{In}$ addition, the EPA decided not to promulgate a rule that would have allowed deferral of the listing of sites on the National Priorities List based on the capability of states to respond. ${ }^{67}$ This leaves open the theoretical possibility that the EPA could interrupt a state's cleanup activities and force it to abide by the provisions of CERCLA.

Thus, the current balance of power under CERCLA heavily favors the federal government over the states. The Supreme Court recently confirmed this imbalance, stating that Congress legitimately used the commerce power to displace the states under CERCLA. ${ }^{68}$ States can mount their own cleanup efforts under state laws, but once the EPA becomes involved, the states play only a secondary role. States suggest sites to be cleaned, assist in the cleanup if the EPA allows them, and intervene in reimbursement actions if the EPA ignores state standards in negotiating a consent decree. $^{69}$ In sum, CERCLA severely circumscribes the role of the states in hazardous waste cleanup.

ot 1989 Colo Rev Stat § 29-22-204.

-s Lawrence E. Starfield, The 1990 National Contingency Plan-More Detail and More Structure, But Still a Balancing Act, 20 Envir L Repr 10222, 10242 (1990).

o6 55 Fed Reg 8783 (1990). The EPA did not want the states to have the ability to commit Superfund money without EPA oversight.

67 55 Fed Reg 8667 (1989). Such deferral exists for sites regulable under RCRA. Starfield, 20 Envir L Repr at 10242 (cited in note 65).

68 Union Gas, $109 \mathrm{~S} \mathrm{Ct}$ at 2284-85.

oง 42 USC §§ 9605(a)(8)(B), 9604(a), 9621(f)(2)(B). 


\section{Policy Implications of the CurRent Scheme}

A. The Theory of Federalism

CERCLA makes the federal government responsible for cleaning up almost all of the serious hazardous waste sites in the country. As we have seen, the federal government may enlist a state's help in a number of secondary roles, but retains a large amount of discretion regarding the extent of state involvement. Complaints have arisen about the system's effectiveness in achieving its goals. ${ }^{70}$ The theory and rationale for our system of federalism illuminate some of the problems and suggest the need for more state control under CERCLA.

Arguments made during the ratification period of the Constitution reveal the Framers' and ratifiers' understanding of the federal system as limited by concerns of state autonomy. For example, James Madison wrote in Federalist 45: "The powers reserved to the several States will extend to all the objects which, in the ordinary course of affairs, concern the lives, liberties and properties of the people, and the internal order, improvement and prosperity of the State." ${ }^{\text {"II }}$ Similarly, James Wilson told the Pennsylvania ratifying convention that "[w]hatever object of government is confined in its operation and effect, within the bounds of a particular state, should be considered as belonging to the government of that state."72 Thus, matters whose effects did not extend beyond the boundaries of a state, as hazardous waste cleanups often do not, were considered primarily state matters.

The federal government's creation and centralization of a national program for cleaning up hazardous waste sites reflects a twentieth-century trend toward increasing federal regulatory control. ${ }^{73}$ This shift dates back at least as far as the New Deal, when "local measures [often] appear[ed] hopelessly inadequate,"

\footnotetext{
${ }^{70}$ See, for example, Surveys and Investigations Staff, $A$ Report to the Committee on Appropriations, United States House of Representatives on the Status of the Environmental Protection Agency's Superfund Program (March 1988). See also Environmental Protection Agency, Oversight of the Environmental Protection Agency's Management Review of the Superfund Program (1989) (responding to criticism).

${ }^{71}$ Federalist 45 (Madison) in Clinton Rossiter, ed, The Federalist Papers 288, 292-93 (Mentor, 1961).

722 Jonathan Elliot, Debates in the Several State Conventions on the Adoption of the Constitution 424 (2d ed 1836) (quoted in Raoul Berger, Federalism: The Founders' Design 71 (U Oklahoma, 1987)) (emphasis in original).

${ }^{73}$ See generally Cass R. Sunstein, Constitutionalism After the New Deal, 101 Harv L, Rev 421, 422-25, 504-08 (1987).

${ }^{74}$ Id at 505.
} 
the increasing economic interdependency of states. In addition, states appeared to be "arenas for factional strife and parochialism," "78 unable to solve a number of pressing problems.

The original justifications for CERCLA reflect this New Deal legacy. Throughout the 1970s, states were widely perceived as ineffectual in drafting and implementing meaningful environmental regulation. Moreover, states were seen as reluctant, even uncooperative, partners with the federal government in implementing federal environmental programs. ${ }^{78}$ When the pressing need for hazardous waste cleanup became apparent, Congress assumed that the national government should take a leading, even dominant, role..$^{77}$ After all, at the time of CERCLA's enactment, only a handful of states had legislation that could even begin to address the problem.

This pessimism about the states' ability to perform adequate cleanups seems to persist within the federal government. ${ }^{78}$ Yet, during the past decade, many states have gained expertise and achieved successes of their own. ${ }^{79}$ These achievements are even more notable given the powerful incentives under the current scheme for states to conserve their resources and remain in the background, letting the federal government shoulder the full burdens of hazardous waste cleanup.

\section{B. Federalism Applied to CERCLA}

1. Interstate coordination.

Many systems of environmental regulation are usefully and efficiently carried out at the federal level due to economies of scale and scope. As one commentator has noted, "[c]ollection of data and analysis of environmental problems, standard setting and (in some instances) selection of control measures involve recurring,

75 Id at 425.

${ }^{76}$ See Stewart, 86 Yale L J at 1198 (cited in note 10).

${ }^{77}$ The original $\S 9614$ (c), which led to the Hunt decision, was one manifestation of this thinking. See text at notes 55-61.

78 See Freedman, 19 Envir L Repr at 10116 (cited in note 19). For example, the Office of Technology Assessment views the states as unable to make a substantial independent contribution to the cleanup. OTA, Superfund Strategy at 24-25 (cited in note 5).

70 See Office of Solid Waste and Emergency Response, Environmental Protection Agency, State Participation in the Superfund Program: CERCLA Section 301(a)(1)(E) Study, Final Report (1984); Carolyn L. Buchholz, Can a Jurisdictional Showdown Under Superfund Be Avoided?, 19 Envir L Repr 10327 (1989). 
technically complex issues; such steps can often be taken far more cheaply [] on the national level."so

National coordination, however, is unnecessary in the context of CERCLA. The Superfund was created to facilitate the cleanup of a large number of hazardous waste sites scattered throughout the country. As noted earlier, these sites are not interconnected: they are discrete and usually within the confines of a single state. ${ }^{81}$ Moreover, as of October 17, 1989, the EPA cannot begin a remedial action until the affected state guarantees that it will provide a federally-approved disposal facility for the removed substances; ${ }^{82}$ thus, even waste disposal occurs within the affected state. Indeed, the entire remedial action is a function that might normally be thought of as within the police power of a state-the protection of local public health.

Similarly, the National Priorities List does not perform a necessary or even very useful coordinating function at the federal level. Some sites are on the National Priorities List simply because each state is guaranteed at least one site on the List. ${ }^{83}$ The rest of the sites are chosen by means of the Hazard Ranking System, ${ }^{84}$ whose underlying scores are based on subjective judgments by evaluators, often state officials. Some evaluators use "realistic" assumptions, while others use "worst case scenarios." The Hazard Ranking System has been changed several times, and it can be manipulated to control the number of sites placed on the List. ${ }^{86}$ Finally, the National Priorities List is somewhat arbitrary, having evolved from an ad hoc, working draft of potential cleanup sites to its current significance as an exclusive list of sites that will receive remedial action. ${ }^{87}$

Although the current system is not well-suited to carry out its purportedly federal objectives, the Hazard Ranking System and National Priorities List could be redesigned to achieve their intended goals. ${ }^{88}$ The EPA's monopoly on hazardous waste cleanup creates other, more serious problems, however. Having only one lo-

${ }^{80}$ Stewart, 86 Yale L J at 1212 (cited in note 10).

${ }^{81}$ See text at notes 3-4.

${ }^{82} 42$ USC \& 9604(c)(9).

ss 42 USC § $9605(\mathrm{a})(8)(\mathrm{B})$.

34 40 CFR \& 300, Appendix A (1989).

${ }^{85}$ See Stever, 1 Law of Chemical Regulation \$ 6.06 at 6-72 (cited in note 14).

${ }^{86}$ Sites do not come off of the List, however, without the state's concurrence. 42 USC § 9621(f)(1)(C).

${ }^{87}$ See Stever, 1 Law of Chemical Regulation $\$ 6.06$ at 6-71 (cited in note 14).

${ }^{83}$ For example, eliminating the requirement that each state gets a site on the National Priorities List and implementing uniform criteria in the Hazard Ranking System for judging 
cus of decisionmaking means that the progress of hazardous waste cleanup is totally dependent on how quickly that one agency can address the problem. In the early 1980s, when inaction in the EPA hindered enforcement of CERCLA, ${ }^{89}$ hazardous waste cleanup was jeopardized across the entire country. Although Congress tried to rectify that situation with SARA, the EPA still has begun less than three hundred of an expected two thousand or more cleanups on the National Priorities List. ${ }^{90}$ The current structure of CERCLA effectively bottles up state resources while the EPA plods through the National Priorities List. CERCLA puts all the national environmental cleanup "eggs" in one basket, thus increasing the risk that no significant cleanups will occur. Absent a need for national coordination, the authority to perform cleanups should be dispersed among the states.

2. Political accountability and sensitivity to local concerns.

The EPA's monopoly on hazardous waste cleanup does not adequately respect the diversity of interests held by the affected states. As Professor Michael McConnell states, "So long as preferences for government policies are unevenly distributed among the various localities, more people can be satisfied by decentralized decisionmaking than by a single national authority." sity of approaches taken by the states to the problem of hazardous waste cleanup in their own statutes reflects different policy tradeoffs with respect to those cleanups. Congress's displacement of state authority under CERCLA is especially puzzling when one considers that local decisionmaking authority has been honored in so many other federal environmental schemes, such as the Clean Air Act, the Clean Water Act, and RCRA. ${ }^{92}$

sites across the nation would improve the National Priorities List as a centralized source of information about those sites needing the greatest attention.

so See generally Frederick R. Anderson, Negotiation and Informal Agency Action: The Case of Superfund, 1985 Duke L J 261, 276-87.

oo BNA Envir Daily 4 (October 31, 1989). Of course, CERCLA does not forbid states to clean up sites on the National Priorities List, but as a practical matter states have little incentive to devote their own resources to cleanups that CERCLA obligates the EPA (eventually) to perform.

'1 Michael W. McConnell, Federalism: Evaluating the Founders' Design, 54 U Chi L $\operatorname{Rev} 1484,1493$ (1987).

${ }^{92}$ See John E. Bonine and Thomas O. McGarity, The Law of Environmental Protection: Cases-Legislation-Policies 320 (West, 1984); and Adam Babich, Coming to Grips with Toxic Waste: The Need for Cooperative Federalism in the Superfund Program, 19 Envir L Repr 10009 (1989). 
From the beginning, CERCLA has required financial assistance from the states. $^{93}$ As discussed earlier, many states responded to this requirement by creating their own "miniSuperfund" laws. Once enacted, states often used these statutes for both CERCLA and non-CERCLA cleanups. Having been drawn into the hazardous waste cleanup business by the federal government, these states have become increasingly interested in administering and implementing cleanup programs. ${ }^{94}$

This emerging state interest has led to wasteful competititon for control of cleanup efforts at individual sites. The Akzo case discussed earlier exemplifies this phenomenon. ${ }^{95} A k z o$ involved a consent decree proposed by the EPA, which suggested one cleanup method-"soil flushing"-instead of the state's preferred remedy-incineration..$^{98}$ Soil flushing is a cheaper remedy, but Michigan contended that the method would have uncertain consequences and that its use might violate state laws. ${ }^{97}$ Thus, the state sought to intervene in the federal action to challenge the proposed consent decree and to require the EPA and the defendants to comply with state law. ${ }^{88}$ This is a striking example of a state and the EPA fighting each other in the courts, with the state trying to force the EPA to impose a stricter, costlier standard on the responsible parties.

CERCLA gives states the right to intervene when the remedial action does not conform to state standards, ${ }^{99}$ but the statute does not require that state standards be satisfied. These rules provide no incentive for the EPA to take state concerns into account when negotiating settlements under CERCLA; in practice, the EPA often ignores state interests. For example, the EPA is currently engaged in consent decree negotiations concerning a site owned by Champion International near Libby, Montana. Despite the state of Montana's requests to participate, the EPA is conducting unilateral negotiations with Champion, limiting Montana to a "consultative role" that effectively "preclude[s it] from any subsequent decisionmaking role concerning activity conducted or results achieved

${ }^{93} 42$ USC $\$ 9604(\mathrm{c})(3)(\mathrm{C})$.

or The majority of state cleanup statutes were enacted after CERCLA. See statutes cited in note 62.

os 719 F Supp at 571.

${ }^{28}$ Id at $574-76$.

97 Id at 576.

98 Id at $577,579$.

๑8 42 USC § 9621(f)(2)(B). 
under the consent decree."100 Moreover, the Justice Department has rejected the possibility of entering into a "memorandum of understanding," which would establish a method for resolving disputes between the federal and state governments over remedies. ${ }^{101}$ Instead, if Montana disagrees with the final negotiated terms, it will be forced to intervene in the federal suit against the potentially responsible parties (as Michigan did in Akzo) and to plead its case before a federal judge. ${ }^{102}$ Such an outcome seems not only wasteful of state and federal resources, but also contrary to fundamental principles of federalism.

Because CERCLA requires only token deference to state concerns, the EPA and the Justice Department are free to ignore or "stiff arm" the states. ${ }^{103}$ Changing the locus of decisionmaking from the state to the federal level decreases political accountability and public involvement, since the EPA is further removed from the people than the state government. ${ }^{104}$ SARA added some provisions for public comment and input at several stages of the negotiation process, but the EPA has only limited incentives to heed this input. In summary, while CERCLA mandates a "substantial and meaningful" role for the states, that guarantee is subverted by procedural rules that allow the federal government to ignore states' interests. ${ }^{105}$

100 See Buchholz, 19 Envir L Repr at 10330 (cited in note 79).

101 Id. The EPA and the state of Massachusetts entered into such an agreement in Massachusetts v Adac Corp., No 89-0307-5 (D Mass 1989). See Buchholz, 19 Envir L Repr at $10330 \mathrm{n} 27$ (cited in note 79).

102 Buchholz, 19 Envir L Repr at 10330 (cited in note 79).

102 John C. Chambers, Jr. and Peter I. Gray, EPA and State Roles in RCRA and CER$C L A, 4$ Natural Resources and Envir 7, 42 (1989) (states cannot rely on what is in the Code of Federal Regulations, because EPA often "stiff arms" the states).

104 See Office of Technology Assessment, Doc No OTA-ITE-362, Are We Cleaning Up? 10 Superfund Case Studies-Special Report 12 (1988) ("EPA is less responsive to community concerns about a remedy being impermanent than to interests which favor a lower cost impermanent remedy.").

108 Another related problem concerns federally controlled facilities that pollute in violation of CERCLA. Frequently the United States Department of Defense is a potentially responsible party under CERCLA, but the states are usually powerless to respond if one part of the Executive Branch (usually the Justice Department) wants to avoid penalizing another. See Babich, 19 Envir L Repr at 10009 (cited in note 92); and Colorado $v$ United States Department of the Army, 707 F Supp 1562 (D Colo 1989). Compare CERCLA to the Clean Air Act, which permits states to force polluting federal facilities to comply with state and local requirements. Clean Air Act, 42 USC \& 7418 (1982 \& Supp 1989). 


\section{A Larger Role for the States Under CERCLA}

As the foregoing discussion indicates, CERCLA is not working as well as its drafters had hoped or intended. In thinking about how CERCLA might be improved, it is important to recognize that many aspects of the statute are worthwhile and effective. Like many other environmental problems, hazardous waste cleanup benefits from cooperation between states and the federal government; state governments vigorously protect local interests and tailor solutions to local concerns, while the federal government sets national standards, provides funding and expertise, and tackles multistate problems. Each government capitalizes on its strengths. Consistent with these institutional capabilities, this Section proposes two ways to increase the states' role in initiation and implementation of hazardous waste cleanups.

\section{A. Return the Initiative to the States}

Many of the other federal environmental statutes combine uniform, federal standards with state implementation. ${ }^{106}$ But CERCLA is just the opposite: the federal government bears the major burden of implementation within a framework of federal and potentially applicable state laws. Most of the Superfund sites, however, are geographically within the borders of individual states and do not generate externalities affecting other states. Therefore, the problems of interstate effects and coordination-the traditional province of the federal government-are generally not present in hazardous waste cleanup. This suggests that the current degree of centralization is unjustified and that the burden of implementation could be more profitably borne by the states.

CERCLA should be amended so that its enforcement and implementation structure more closely resemble that of the Clean Air Act. Under the proposed revision of CERCLA, federal law would mandate a certain number of state-initiated cleanups of National Priorities List sites to be completed within a certain length of time. ${ }^{107}$ CERCLA would continue to impose liability on responsible

\footnotetext{
106 See, for example, the Clean Air Act, 42 USC \& 7410 (State Implementation Plans), $\S 7408$ (National Ambient Air Quality Standards); RCRA, 42 USC §§ 6926, 6929, 2931, 6946-48, 6961, 6972, 6992f; and Clean Water Act, 33 USC §§ 1342, 1370 (1982 \& 1989 Supp).

${ }_{107}$ The EPA would continue to maintain the National Priorities List as an informational aid to the states and for its own use in oversight activities. On the other hand, Remedial Investigations and Feasibility Studies (RI/FS), which are the studies the EPA does to determine the extent of the danger at a site and propose a remedy for that site, are probably better handled at the state level because they are site-specific and because the state, not the
} 
parties for the past dumping of certain specified substances, as it does now, but only the states would have statutory authority to bring enforcement actions. Which sites to clean and which actions to bring are decisions that should be left to the discretion of the states. ${ }^{108}$ If a cleanup were beyond the expertise of a state, the EPA would be allowed to assist the state in the cleanup, but only at the state's request.

The revised CERCLA should also allow the EPA to maintain an oversight role by requiring EPA approval of state remedial plans. ${ }^{109}$ The EPA would assess the remedial plans against the $\mathrm{Na}$ tional Contingency Plan, which would remain in effect and preempt state law to the extent that state standards were less stringent.110 But CERCLA should ensure that the National Contingency Plan is focused on the cleanliness of sites, not on preference of certain technological methods of cleanup. If the state demonstrates to the EPA that a remedial action chosen by the state will achieve the level of cleanliness required by the National Contingency Plan by whatever means, then the EPA Administrator must approve it. ${ }^{111}$

Under the proposal, preemption of state standards that do not meet certain minimal criteria furthers several policies. First, a uniform floor throughout the country would eliminate the so-called "race to the bottom," the incentive for states to relax their cleanup standards in an effort to encourage business development. Yet above the minimum specified by federal law, states would be free to make their own tradeoffs. Thus, the proposal preserves a substantial amount of state autonomy while ensuring that a minimum level of hazardous waste cleanup will be achieved. Second, uniform minimum standards reduce in part the transaction costs that would result from a completely decentralized system; ex ante

federal government, will normally act on the RI/FS by cleaning up the site. With EPA permission, states are currently authorized to perform RI/FS in state-directed remedial actions. See Freedman, 19 Envir L Repr at 10135 (cited in note 19).

${ }^{108}$ This Comment does not address the extent to which there should be private rights of action under CERCLA, either for injuries sustained or as a supplement to enforcement.

109 This is also similar to the Clean Air Act. See Bonine and McGarity, Law of Environmental Protection at 320 (cited in note 92).

${ }^{110}$ Many states already require their hazardous waste cleanups to conform to the National Contingency Plan whenever possible, so the transition should not be costly or diffcult. See, for example, NJ Rev Stat § 58:10 - 23.11f(a).

111 This has a parallel in the Clean Air Act, in which the EPA Administrator must approve State Implementation Plans if she finds that the Plan will comply with the National Ambient Air Quality Standards. See 42 USC § 7410(a)(2); and Union Electric $v$ EPA, 427 US 246 (1976). 
agreement on the standards will defuse some of the antagonism between the states, the responsible parties, and the federal government. ${ }^{112}$ Third, preemption ensures that states pursue permanent remedies, as required by the National Contingency Plan and CERCLA. ${ }^{113}$

In effect, CERCLA currently establishes a presumption that the EPA will carry out the cleanup; generally, states may assume the federal role only with the EPA's permission. The revised CERCLA reverses that presumption: states have primary responsibility for cleanup, and the EPA may intervene only with the permission of the affected state. The EPA retains the ability to become involved at the state's request in remedial actions because some projects are too big or too complicated for individual states to handle alone. States may choose to enlist the aid of the federal government, which may have more expertise or resources. This potential for federal action and the need for maintaining minimum federal standards suggest that states should notify the EPA before undertaking cleanup actions. Even if states enlist the federal government to clean most sites, the revised CERCLA is preferable to EPA centralization because of the political accountability and comity concerns discussed earlier.

Because states assume primary responsibility for cleanups under the revised CERCLA, a state may take action either under its own laws or under CERCLA. In either case, however, the primary source of funding should be from the states. Simply having a large federal fund to finance state-led efforts would create other problems associated with federalism. When the federal government provides a common pool of funding for the states to use in predominantly local projects, each state will be relieved from considering its own budgetary constraints and will demand more from the federal fund than it would otherwise spend itself. ${ }^{114}$ The Superfund should remain dedicated primarily to federal actions (i.e., remedial actions performed by the EPA at the request of a state).

This revised CERCLA returns a large measure of self-determination to the states in the cleanup of hazardous wastes. State governments are likely to be more responsive, and the EPA is too far removed from the affected people in many instances to effectively

\footnotetext{
112 Recall the wasteful battles now taking place in the federal courts between state governments, the EPA, and the Justice Department. See Section III.

11342 USC \$ 9621(b)(1).

114 See McConnell, 54 U Chi L Rev at 1496 (cited in note 91).
} 
meet the needs of a particular situation. ${ }^{115}$ Therefore, the proposed revision responds to the major federalism objection under the current CERCLA scheme: intrastate matters could be resolved by local officials elected by the affected groups.

It may well be that in 1980, when CERCLA was passed, the states were not prepared to assume the responsibility of cleaning up the nation's hazardous waste sites, but the increasing interest and involvement of states suggests that they now are. While the federal government may have a certain comparative expertise, it lacks sensitivity to local needs. The states, therefore, should assume primary responsibility for the implementation of hazardous waste cleanups.

\section{B. Allow States to Sue for Injunctions in Federal Court}

In addition to initiating hazardous waste cleanup, states should have the right to sue polluters for federal injunctions under CERCLA. As discussed in Section I, CERCLA currently allows states to enforce only the provisions of existing consent decrees in federal court.

Under this second proposed revision of CERCLA, states would have the same power as the President to "secure such relief as may be necessary to abate such danger or threat"116 in the federal courts. This power to seek an injunction gives the states an additional weapon against sudden spills or emergencies. ${ }^{117}$ Injunctions are cheaper than government-sponsored cleanups in two ways. ${ }^{118}$ First, the government cannot always expect to recover all of its costs in an action for reimbursement because CERCLA provides defenses (albeit limited), and because it sometimes proves impossible to establish which parties are responsible. ${ }^{119}$ Second, the government does not have the same profit motive as private firms; private firms are probably in a better position to find the cheapest ways of performing the cleanups.

Since the passage of CERCLA, the federal courts have construed the statute broadly in favor of allowing injunctive actions for abatement to go forward. For example, one court, analyzing the

\footnotetext{
115 See Sunstein, 101 Harv L Rev at 505 (cited in note 73) ("[I]t is no longer credible to believe that federal agencies can serve as an outlet for democratic aspirations.").

11842 USC § 9606(a).

112 See text at note 45 .

118 See generally Note, Allocating the Costs of Hazardous Waste Disposal, 94 Harv L Rev 584, 593-95 (1981).

${ }^{129}$ See 42 USC \& 9607(b).
} 
requirement of "imminent and substantial endangerment," held that "endangerment" means only potential harm, and that "imminent" can include situations in which the harm will not occur for several years. ${ }^{120}$ Another court held that the endangerment requirement is met by a showing that there "may be risk of harm," and that the "substantial endangerment" need not be quantified. ${ }^{121}$ Moreover, the government need not satisfy the traditional equitable requirement showing irreparable harm in suits for injunctions. ${ }^{122}$ If the federal courts continue to interpret CERCLA broadly for purposes of granting injunctions, states will have a very powerful tool at their disposal.

\section{Conclusion}

Congress's decision to vest most of the decisionmaking and implementation authority of the Superfund program in the federal government makes CERCLA an oddity among federal environmental statutes. ${ }^{123}$ Most major environmental legislation, including the Clean Air Act, the Clean Water Act, and RCRA (the other half of Congress's approach to the hazardous waste problem) involve the states to a much greater extent than does CERCLA. Yet the rationales underlying those laws apply at least as well to CERCLA.

Two fundamental shifts in the structure and philosophy of CERCLA should be enacted. First, control over the implementation of remedial actions under CERCLA should be given to the states. The EPA could maintain an oversight and advisory role and could intervene in a remedial action with the state's permission. Shifting the major decisionmaking authority from the EPA to the states enhances political accountability and better comports with principles of federalism. Second, the states should be allowed to enjoin polluters in federal court under CERCLA. This power complements increased state responsibility for implementation of the program, and it should produce less costly solutions in many cleanups.

As David Stockman said, the federal government "cannot do everything"; ${ }^{124}$ nor was it intended to do everything. In the context of environmental regulation, self-determination and local control over local matters are important principles. It is troublesome that

\footnotetext{
${ }_{120}$ B.F. Goodrich v Murtha, 697 F Supp 89, 96-97 (D Conn 1988).

121 United States v Conservation Chemical Co., 619 F Supp 162, 194 (W D Miss 1985).

${ }^{222}$ Murtha, 697 F Supp at 96.

${ }^{123}$ See Babich, 19 Envir L Repr at 10009-11 (cited in note 92).

124 See note 1 .
} 
states must wait for the EPA to undertake these vital cleanup projects. Deferring to federalism concerns and the recent practical expertise acquired by the states in environmental cleanups, Congress should empower the states to control the initiation and enforcement of these projects. 
